\title{
PREDICTION OF THE ANTICLASTIC SHAPE CHANGES OF HYBRID COMPOSITE MATERIAL
}

\author{
Andris Baikovs ${ }^{1}$, Kārlis Rocēns ${ }^{2}$ \\ Riga Technical University, Azenes street 16, LV-1048 Riga, Latvia \\ E-mail: ${ }^{1}$ abpasts@inbox.lv; ${ }^{2}$ rocensk@latnet.lv \\ Received 29 Sept. 2009; accepted 16 Dec. 2009
}

\begin{abstract}
In search of structurally better and aesthetically more attractive solutions of the erection of various structures, non-standard anticlastic elements are used more frequently. Therefore preservation of the initial shape of timber composite material sheets by using of reinforced plastic reinforcement has been investigated. Calculation model for determination of the thickness of rational reinforcement anticlastic sheet, which provides change of the original bending radius under variable moisture conditions (Baikovs and Rocens, 2006) within the limits of preferable intervals is developed by authors and using finite element method, calculations and modelling of sheet deformations are carried out with software package ANSYS v.11 (henceforth FEM) and by developed analytical method. Comparative research of the results calculated with the FEM and developed calculation model showed that the difference between results in the three cases investigated, when the composite timber material is reinforced on the top, bottom and both sides for the most of the cases does not exceed $3.3 \%$. An opportunity to provide the original shape of anticlastic timber composite material sheets by using glass fibre reinforced plastic reinforcement under variable moisture conditions and not exceeding the difference of $5 \%$ has been demonstrated.
\end{abstract}

Keywords: displacements; moisture changes; composite timber material; glass fibre plastic; reinforcement.

\section{Introduction}

Layered composite material sheets are widely used in the construction and transport machine-building industry, where part of structural elements are under variable moisture conditions during time of operation and erection, which often leads to changes of the initial shape of these elements and to structural inadequacy regarding the requirements of normative acts. In search of structurally better and aesthetically more attractive solutions of the construction of various structures, non-standard anticlastic elements are more frequently used. If the anticlastic composite material sheets are used in cable roof structures as either load bearing covering elements or isolating elements in interior decoration, then due to variable moisture, undesirable changes of the shape of elements are caused, which can partly be prevented by use of reinforced plastic reinforcement. Therefore preservation of the initial shape of timber composite material sheets using reinforced plastic reinforcements has been investigated.

Calculation model for determination of the thickness of anticlastic sheet rational reinforcement, which provides changes of the original bending radius within the limits of preferable intervals under variable moisture conditions (Baikovs and Rocens 2006) developed by the authors and FEM are used for the modelling of sheet deformations. The aim is to evaluate and compare results, determined using previously developed and approbated calculation model (Baikovs and Rocens 2006) and FEM.

\section{Calculation model}

Calculation model for the anticlastic sheet element, which consists of linearly elastic orthotropic layers (henceforth sheet) is developed, in case of plane stress statements of laminated material mechanics in matrix form, discussed in the works Ashton et al. (1969), Reissner and Stavsky (1961), Роценс, Штейнертс (1976), Skudra and Skudra (2002), (Tsai and Pegano 1968) are used. The sheet's layers are assumed to be tied together by a thin layer of glue, as a result of which they deform together. Threshold of the orthogonal coordinate system is placed in the centre of geometrical middle plane of sheet. The case with identical moisture content for every sheet's layer under any moisture changes is considered. In the operating conditions moisture distribution along the cross-section of the element is variable, but the considered case is more dangerous, because it gives larger effect on the change in bending radiuses. The changes of the longitudinal deformations in geometrical middle plane of the sheet and bending radiuses of the sheet bottom surface (Fig. 1) are assumed to be the main characteristics of invariability of the shape.

Calculation of the shape invariability characteristics under variable moisture, for the element obtained by reinforcement of the sheet with reinforced plastics (henceforth element), is carried out in several stages. In the first stage how large the moisture change $\Delta \widehat{W}$ has to be, to straighten the anticlastic sheet is calculated. It is assumed that both curvature radiuses of the sheet become equal to 
almost in the same moment. Calculations by choosing the appropriate moisture change (reducing the moisture until the sheet straightens out), or knowing a definite moisture change, which has already provided the required curvature of flat composite material sheet are carried out. At the beginning longitudinal deformations ${ }_{n}$ and shear strain $n$, caused by moisture changes $W$, are determined at distances $z_{0}$ and $z_{n}$ from geometrical middle plane of an non-reinforced composite material sheet (Fig. 1):

$$
\begin{array}{cccccc} 
& & 0 & & \\
x & x_{x} & & \\
& & y^{0} & z_{n} & k_{y} & \text {, where } \\
y & & y^{0} & & \\
x y & n & x y & & k_{x y} &
\end{array}
$$

- middle plane deformations of the layered element:

$$
\begin{array}{ccccc}
{ }_{x}^{0} & & N_{x} & & M_{x} \\
{ }^{0} & A & N_{y} & B & M_{y} \\
{ }_{x y} 0 & & N_{x y} & & M_{x y}
\end{array}
$$

- middle plane curvature of the layered element

$$
\begin{aligned}
& \begin{array}{ccc}
k_{X} & N_{X} & M_{X}
\end{array} \\
& \begin{array}{llllll}
k_{y} & B & N_{y} & D & M_{y}
\end{array} \text {. } \\
& k_{x y} \quad N_{x y} \quad M_{x y}
\end{aligned}
$$

Internal forces caused by moisture:

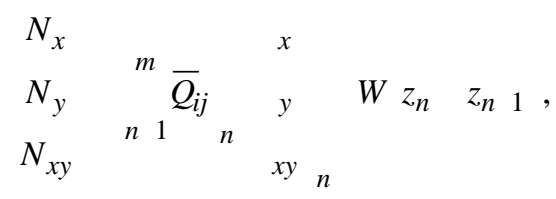

where $i, j=1,2,6$; is the moisture expansion coefficient, where $x$ and $y$ indicates the direction of the property, but $n$ indicates the distance from the top of the sheet; $m$ - the number of layers.

Internal moments caused by moisture:

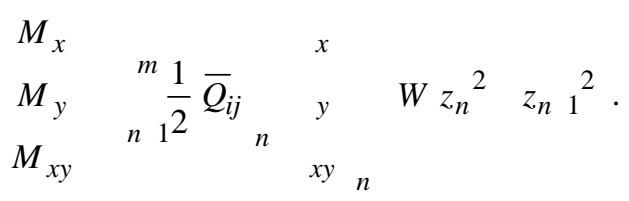

Formulae used for construction of matrixes $A, B, D$ :

$$
\begin{gathered}
A \quad{ }^{1} \quad A{ }^{1} B D \quad B A{ }^{1} B{ }^{1} B A{ }^{1}, \\
B \quad A{ }^{1} B(D), \\
D \quad D \quad B A{ }^{1} B{ }^{1},
\end{gathered}
$$

where the member ,ij” of an axial strength matrix for the whole element:

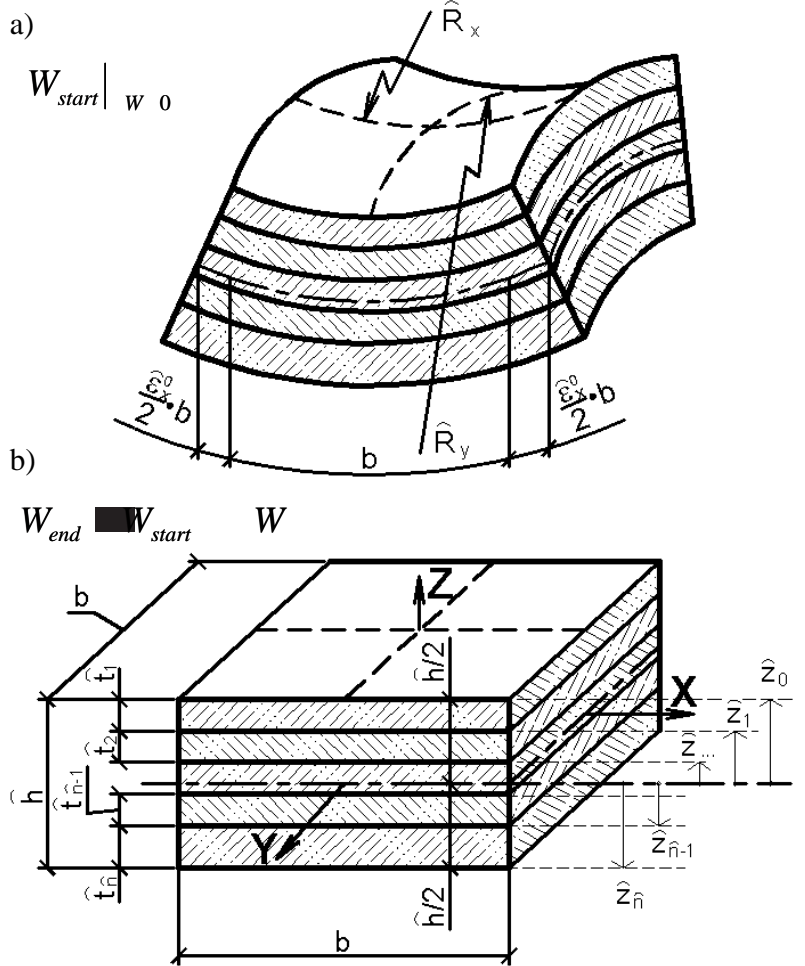

Fig. 1. Calculable elements of the sheet: a) before moisture changes; b) after moisture changes

$$
A_{i j}{ }_{n 1}^{m}\left(\bar{Q}_{i j}\right)_{n}\left(\begin{array}{lll}
z_{n} & z_{n} & 1
\end{array}\right),
$$

(here and hereafter $i, j=1,2,6$ )

- the member „ij” of interacting strength matrix for the whole element:

$$
B_{i j} \quad \frac{1}{2}{ }_{n 1}^{m}\left(\bar{Q}_{i j}\right)_{n}\left(\begin{array}{lll}
z_{n}^{2} & z_{n} 1^{2}
\end{array}\right)
$$

- the member „ij” of bending strength matrix for the whole element:

$$
D_{i j} \quad \frac{1}{3}{ }_{n 1}^{m}\left(\bar{Q}_{i j}\right)_{n}\left(z_{n}^{3} z_{n} 1^{3}\right) .
$$

The reduced strength matrix of $n$th layer in the direction of main axes:

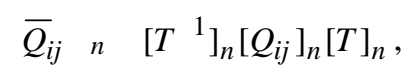

where - transformation matrixes:

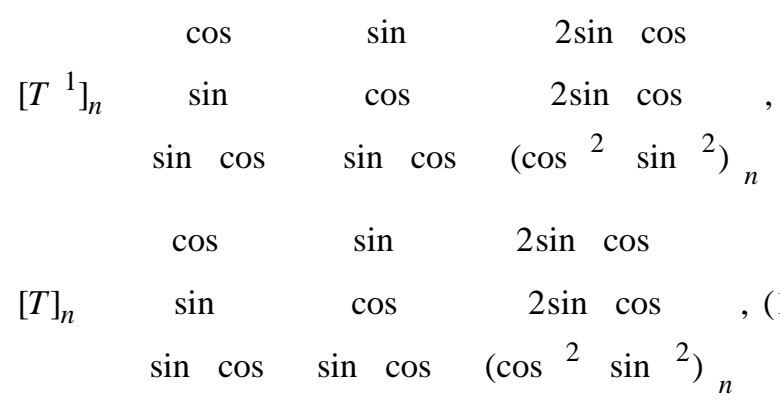


where $\alpha$ is the rotation angle that defines the orientation of layer;

- the reduced strength matrix in the directions of main local axes of $n$th layer:

$$
\left[Q_{i j}\right]_{\hat{n}}=\left[\begin{array}{ccc}
Q_{11} & Q_{12} & 0 \\
Q_{12} & Q_{22} & 0 \\
0 & 0 & Q_{66}
\end{array}\right]_{\widehat{n}},
$$

or using technical deformative characteristics:

$$
\left[Q_{i j}\right]_{\hat{n}}=\left[\begin{array}{ccc}
\frac{E_{1}}{1-v_{12} v_{21}} & \frac{v_{12} E_{2}}{1-v_{12} v_{21}} & 0 \\
\frac{v_{21} E_{1}}{1-v_{21} v_{12}} & \frac{E_{2}}{1-v_{21} v_{12}} & 0 \\
0 & 0 & G_{12}
\end{array}\right]_{\hat{n}}
$$

To calculate the longitudinal deformations $\widetilde{\varepsilon}_{n}$ of the element, which occurs due to the moisture change $\Delta W=\Delta \widehat{W}-\Delta \widetilde{W}$, in the second stage reinforced sheet without any initial curvature subjected to moisture changes $\Delta \widehat{W}$ (Fig. 2) is inspected conditionally.

Longitudinal deformations $\tilde{\varepsilon}_{\mathbf{n}}$, caused by moisture change $\Delta \widehat{W}$

$$
\left[\begin{array}{c}
\tilde{\varepsilon}_{x} \\
\tilde{\varepsilon}_{y} \\
\tilde{\gamma}_{x y}
\end{array}\right]_{n}=\left[\begin{array}{c}
\tilde{\varepsilon}_{x}^{0} \\
\tilde{\varepsilon}_{y}^{0} \\
\tilde{\gamma}_{x y}^{0}
\end{array}\right]+z_{n}\left[\begin{array}{c}
\tilde{k}_{x} \\
\tilde{k}_{y} \\
\tilde{k}_{x y}
\end{array}\right]
$$
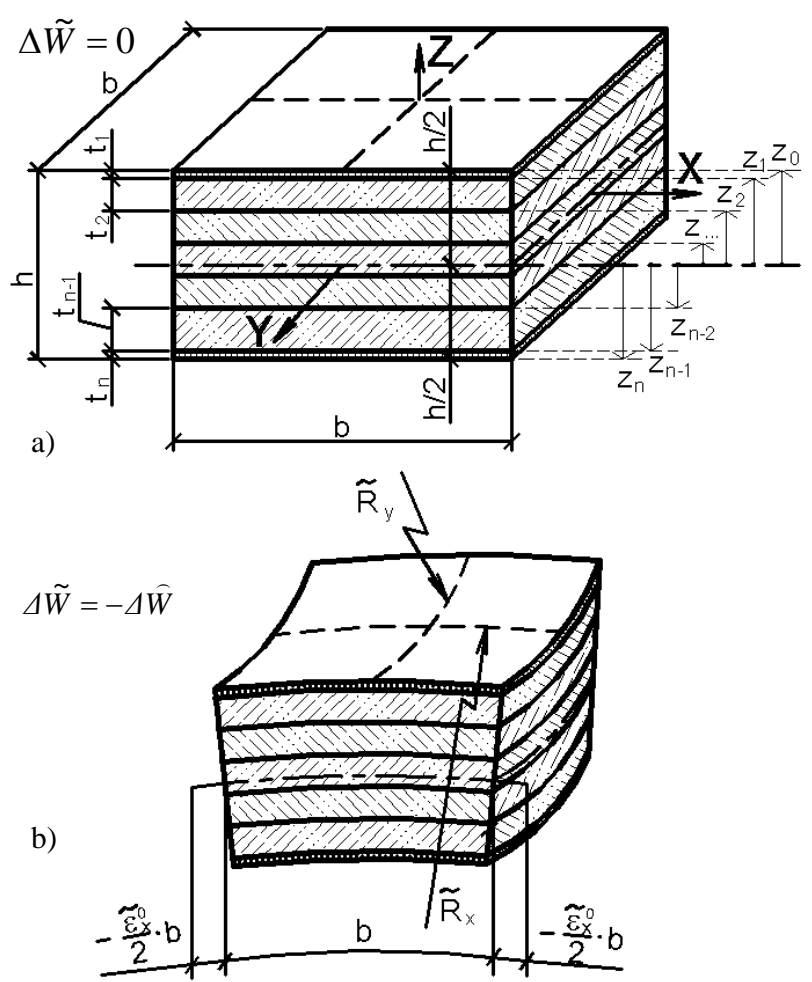

Fig. 2. Calculable element strengthened with reinforced plastic sheet: a) before moisture changes; b) after moisture changes where middle plane deformations of the layered element:

$$
\left[\begin{array}{c}
\tilde{\varepsilon}_{x}{ }^{0} \\
\tilde{\varepsilon}_{y}{ }^{0} \\
\tilde{\gamma}_{x y}{ }^{0}
\end{array}\right]=\tilde{A}^{\prime}\left[\begin{array}{c}
\tilde{N}_{x} \\
\tilde{N}_{y} \\
\tilde{N}_{x y}
\end{array}\right]+\tilde{B}^{\prime}\left[\begin{array}{c}
\tilde{M}_{x} \\
\tilde{M}_{y} \\
\tilde{M}_{x y}
\end{array}\right]
$$

- middle plane curvature of the layered element:

$$
\left[\begin{array}{c}
\tilde{k}_{x} \\
\tilde{k}_{y} \\
\tilde{k}_{x y}
\end{array}\right]=\tilde{B}^{\prime}\left[\begin{array}{c}
\tilde{N}_{x} \\
\tilde{N}_{y} \\
\tilde{N}_{x y}
\end{array}\right]+\tilde{D}^{\prime}\left[\begin{array}{c}
\tilde{M}_{x} \\
\tilde{M}_{y} \\
\tilde{M}_{x y}
\end{array}\right] .
$$

Internal forces caused by moisture:

$$
\left[\begin{array}{c}
\tilde{N}_{x} \\
\tilde{N}_{y} \\
\tilde{N}_{x y}
\end{array}\right]=\sum_{n=1}^{m}\left[\bar{Q}_{i j}\right] n\left[\begin{array}{c}
\beta_{x} \\
\beta_{y} \\
\beta_{x y}
\end{array}\right]_{n} \Delta \tilde{W}\left(z_{n}-z_{n-1}\right) .
$$

Internal moments caused by moisture:

$$
\left[\begin{array}{c}
\tilde{M}_{x} \\
\tilde{M}_{y} \\
\tilde{M}_{x y}
\end{array}\right]=\sum_{n=1}^{m} \frac{1}{2}\left[\bar{Q}_{i j}\right]\left[\begin{array}{c}
\beta_{x} \\
\beta_{y} \\
\beta_{x y}
\end{array}\right]_{n} \Delta \tilde{W}\left(z_{n}{ }^{2}-z_{n-1}{ }^{2}\right) .
$$

Matrixes A', B', D’, $\left[\bar{Q}_{i j}\right] n$ are established analogically like the relevancies (6)-(16), but the index „,, ” has to be replaced with index , $n$ ”.

In the third stage the resultant longitudinal deformations $\varepsilon_{n}$ of the element, which has been subjected to the moisture action and changed moisture content by $\Delta W$ are calculated using relevance:

$$
\varepsilon_{n-1}=\widehat{\varepsilon}_{\hat{n}}+\widetilde{\varepsilon}_{n-1},
$$

where, $\varepsilon$ - longitudinal deformation; $n$ - Index which specifies the number of layers contact plane in the place where longitudinal deformation of the element is calculated. The planes are numbered from the top surface, starting with " 0 ”; $\hat{n}$-Index which specifies the number of layers contact plane in the place where longitudinal deformation of the sheet is calculated.

To define the bending radii on the top and bottom surfaces of the element, an equation system (23) basing on the relationship between the angle $\alpha$ and the sides of right-angled triangle (shown in Fig. 3) is constructed, from which the bending radius $\left.R_{X}\right|_{Z n-1}$ (23) of the bottom surface is determined.

$$
\left\{\left.\begin{array}{l}
\operatorname{tg} \alpha_{x}=\frac{\hat{h}}{\left.\Delta l_{x}\right|_{Z n-1}-\left.\Delta l_{x}\right|_{Z 1}} \\
\operatorname{tg} \alpha_{x}=\frac{\left.R_{x}\right|_{Z n-1}}{\frac{b}{2}+\left.\Delta l_{x}\right|_{Z n-1}}
\end{array} \Rightarrow R_{x}\right|_{Z n-1}=\frac{\hat{h} \cdot\left(\frac{b}{2}+\left.\Delta l_{x}\right|_{Z n-1}\right)}{\left.\Delta l_{x}\right|_{Z n-1}-\left.\Delta l_{x}\right|_{Z 1}},\right.
$$


and

$$
\left.\Delta l_{X}\right|_{Z n}=\left.\varepsilon_{x}\right|_{Z n} \cdot \frac{b}{2},
$$

where $\hat{h}$ - total thickness of the sheet; $b$-width of the sheet; $\left.\Delta l_{x}\right|_{Z n-1}$ - longitudinal elongation in the direction of $\mathrm{X}$ axis. Member $z_{n}$ specifies the location where the elongation is calculated.

The difference between the bending radiuses of the element $\left.R_{X}\right|_{Z n-1}$ and sheet $\left.\widehat{R}_{X}\right|_{Z \hat{n}}$ characterizes influence of the reinforcement at definite moisture change. Analogical relevancies are used to calculate the bending radius $\left.R_{y}\right|_{Z n-1}$.

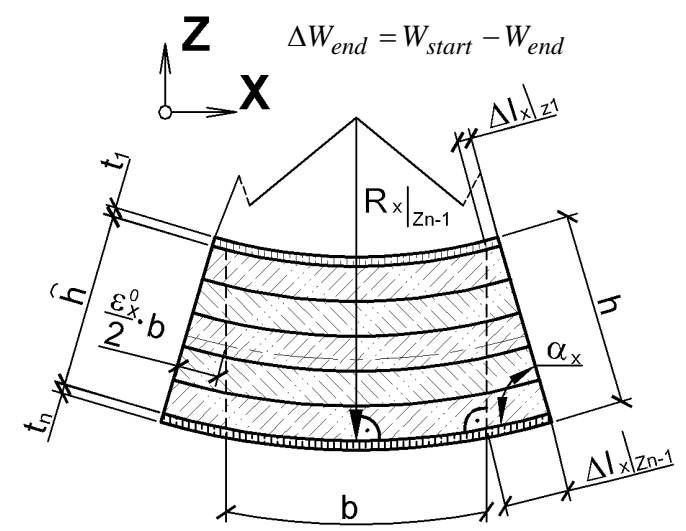

Fig. 3. Calculation scheme of bending radius in plane XZ for the element

The interaction of curvatures in the developed calculation model is not considered, when the moisture changes gradually, therefore precision check of this model is done by comparing analytically calculated results with the results acquired using FEM.

\section{Discussion of results}

During exploitation under variable moisture conditions the sheet from composite timber materials is subjected to undesirable changes of the shape, prevention of which by applying a glass fibre sheet with oriented glass fibres and epoxy resin (henceforth GFRP) is analytically approbated. Characteristic values of GFRP rigidity are found in (Composites materials handbook. Volume 3, 2002) and shown in the Table 1.

In Cases of the sheet with unsymmetrical structure consisting of five birch timber layers glued together, properties of timber values of which found in (Уголев 2007) (Table 1), are used. The longitudinal fibres of the layer are oriented at right angles towards the longitudinal fibres of adjacent layers $\left(90^{\circ} / 0^{\circ} / 90^{\circ} / 0^{\circ} / 90^{\circ}\right)$. The layer thicknesses' are $\widehat{\mathrm{t}}_{1}=\mathrm{t}_{2}=\widehat{\mathrm{t}}_{3}=\widehat{\mathrm{t}}_{4}=1.6 \mathrm{~mm}, \mathrm{t}_{5}=1.7 \mathrm{~mm}$

(Fig. 5). Moisture change $\Delta \widehat{\mathrm{W}}=7 \%$ is the difference between final and initial moisture of the timber layer, for example, when moisture in the timber changes within the limits of $10 \%$ to $17 \%$ if relative humidity of the air changes from $53 \%$ to $82 \%$ with the air temperature of $20^{\circ} \mathrm{C}$ (see Amburgey et al. 1999: Table 3-4).
Table 1. Deformative characteristics of layer properties

\begin{tabular}{c|c|c|c}
\hline Characteristics & Birch-tree $^{1}$ & Birch-tree $^{2}$ & $\begin{array}{c}\text { GFRP } \\
\text { S2/3501-5 }[0 / 90]_{2 \mathrm{~s}}\end{array}$ \\
\hline $\mathrm{E}_{\mathrm{X}}[\mathrm{MPa}]$ & 17250 & 480 & 32300 \\
\hline $\mathrm{E}_{\mathrm{y}}[\mathrm{MPa}]$ & 480 & 17250 & 32300 \\
\hline $\mathrm{E}_{\mathrm{z}}[\mathrm{MPa}]$ & 645 & 645 & 16500 \\
\hline $\mathrm{G}_{\mathrm{xy}}[\mathrm{MPa}]$ & 890 & 890 & 6760 \\
\hline $\mathrm{G}_{\mathrm{xz}}[\mathrm{MPa}]$ & 1540 & 230 & 5670 \\
\hline $\mathrm{G}_{\mathrm{yz}}[\mathrm{MPa}]$ & 230 & 1540 & 5670 \\
\hline$v_{\mathrm{xy}}$ & 0.445 & 0.013 & 0.136 \\
\hline$v_{\mathrm{xz}}$ & 0.341 & 0.321 & 0.435 \\
\hline$v_{\mathrm{yz}}$ & 0.321 & 0.341 & 0.435 \\
\hline$\beta_{\mathrm{X}}$ & 0 & 0.0034 & 0 \\
\hline$\beta_{\mathrm{Y}}$ & 0.0034 & 0 & 0 \\
\hline$\beta_{\mathrm{Z}}$ & 0.0028 & 0.0028 & 0
\end{tabular}

${ }^{1} \mathrm{X}$ axis is parallel to the direction of longitudinal fibres;

${ }^{2} \mathrm{Y}$ axis is parallel to the direction of longitudinal fibres.

Indexes shown in the table 1 indicates the properties of layer in the global coordinate system. If the $\mathrm{X}$ axis indicates the direction parallel to the fibres (see 2.column in the Table 1), then index $\mathrm{Y}$ indicates the direction of the property transversally to the fibres of timber layer, but $\mathrm{Z}$ - in the radial direction.

Declared values for modulus of elasticity $E$ of birch are calculated by dividing the sum of modulus of elasticity in tension and compression (found in Уголев 2007) by 2. G - shear modulus. The first index of Poisson's ratio $v$ indicates the direction of load, the other the direction of transverse deformations.

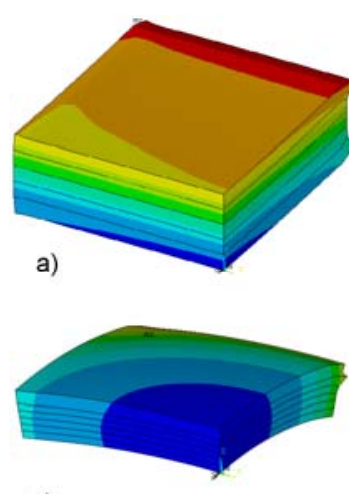

c)

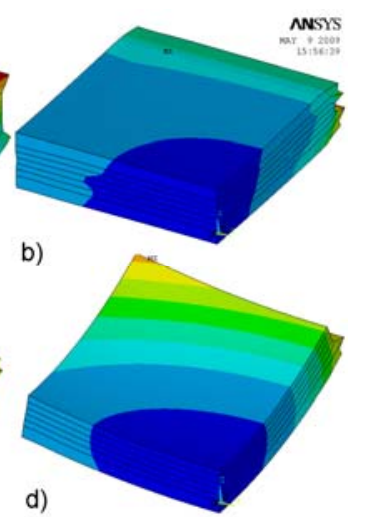

d)
Fig. 4. Visualization of the displacements (enlargement $50 \times$ ) calculated with ANSYS v.11 for the one fourth part of the sheet: a) Displacements of the anticlastic sheet, with curvature obtained after the moisture growth of $7 \%$ (from $\widehat{W}_{\text {start }}=10 \%$ to $\widehat{\mathrm{W}}_{\mathrm{end}}=17 \%$ ). Displacements of the anticlastic element strengthened from b) both sides, c) top side and d) bottom side with the glued GFRP sheet after moisture decrease of $7 \%(\mathrm{~W}=10 \%)$

Using FEM and developed calculation model (Baikovs and Rocens 2006) three cases were analytically approbated: the sheet curved by moisture were reinforced on the concaved surface (Fig. 4c), arched surface (Fig. 4d) and on the both sides (Fig. 4b). Case if the thicknesses of GFRP reinforcement sheets are $\mathrm{t}_{\mathrm{GFRP}}=3.15 \mathrm{~mm}$ was analysed, because using doublesided reinforcement with such thickness the invariability of the both bending radiuses of the element has been provided with the precision which does not exceeds $5 \%$ admissible in engineering calculations. In the case of doub- 
le-sided GFRP reinforcement with the thickness $3.15 \mathrm{~mm}$ (ratio of reinforcement cross - section area to total element's cross-section area $æ=0.44$ ) for the moisture decrease of $\Delta \mathrm{W}=7 \%$, the change of the element's bending radius parallel to the direction of $\mathrm{X}$ axis is $-1.19 \%$, in the direction of Y axis $-4.97 \%$ (Fig. 5), if the developed calculation model is applied. If the thickness of strengthening is $1.30 \mathrm{~mm}(æ=0.24)$ then the change of the element's bending radius parallel to the direction of $\mathrm{X}$ axis is $4.96 \%$, but in the direction of $\mathrm{Y}$ axis is $20.10 \%$ - the invariability is provided only for the bending radius parallel to the $\mathrm{X}$ axis.

It is assumed with in developed calculation model that the curvature of the element is spherical, but results of FEM show that for most cases of elements with unsymmetrical structure, shape of obtained curvature is elliptical greatest bending radius is on the edges of the element, but the smallest in the place where intersects the geometrical symmetry axis. Therefore for the comparison of the results the values of bending radiuses obtained in the middle part of the FEM calculation model were used, or in between maximum and minimum values of bending radiuses ( $2.5 \mathrm{~mm}$ from the edges of element). For the selected type of finite element FEM does not calculate the values of the bending radiuses in the middle plane of the element, therefore radiuses were calculated basing on the geometrical relationships and values of displacements calculated by FEM. Difference between the values of bending radiuses calculated using developed calculation method and FEM does not exceed $2.7 \%$ for the case of non reinforced sheet, $10.7 \%$ for the double-sided reinforcement and $2.7 \%$ for the one-sided reinforcement (Table 2).

Table 2. Maximum differences between the results calculated using FEM and developed calculation method if the moisture changes by $7 \%$

\begin{tabular}{c|c|c|c|c}
\hline \multirow{2}{*}{ Bending radius } & \multirow{2}{*}{ Sheet } & \multicolumn{3}{|c}{ Placement of strengthening } \\
\cline { 3 - 5 } & & Double & Top & Bottom \\
\hline $\mathrm{R}_{\mathrm{X}}$ & 2.7 & 2.9 & 2.7 & 2.7 \\
\hline $\mathrm{R}_{\mathrm{y}}$ & -1.4 & -10.7 & 1.3 & 2.1 \\
\hline
\end{tabular}

Only in the one of the six inspected cases for the element with different GFRP placements (Fig. 5), the difference between results exceeds $5 \%$ - in the case with the smallest curvature, therefore can be concluded that developed method is sufficiently precise and applicable in calculations of surface curvatures.

Developed model can also be used if changes of curvature caused by moisture are used for the manufacturing of elements with anticlastic surface. The best of all such curvatures can be accomplished by use of one-sided reinforcement. The curvature of the sheet will increase or decrease depending on placement of reinforcement, properties and thickness. For example, when the top surface of the sheet is reinforced with GFRP, the curvatures tends to increase - if the moisture decrease is $\sim 1 \%$ concaved curvature parallel to the direction of $\mathrm{X}$ axis changes and

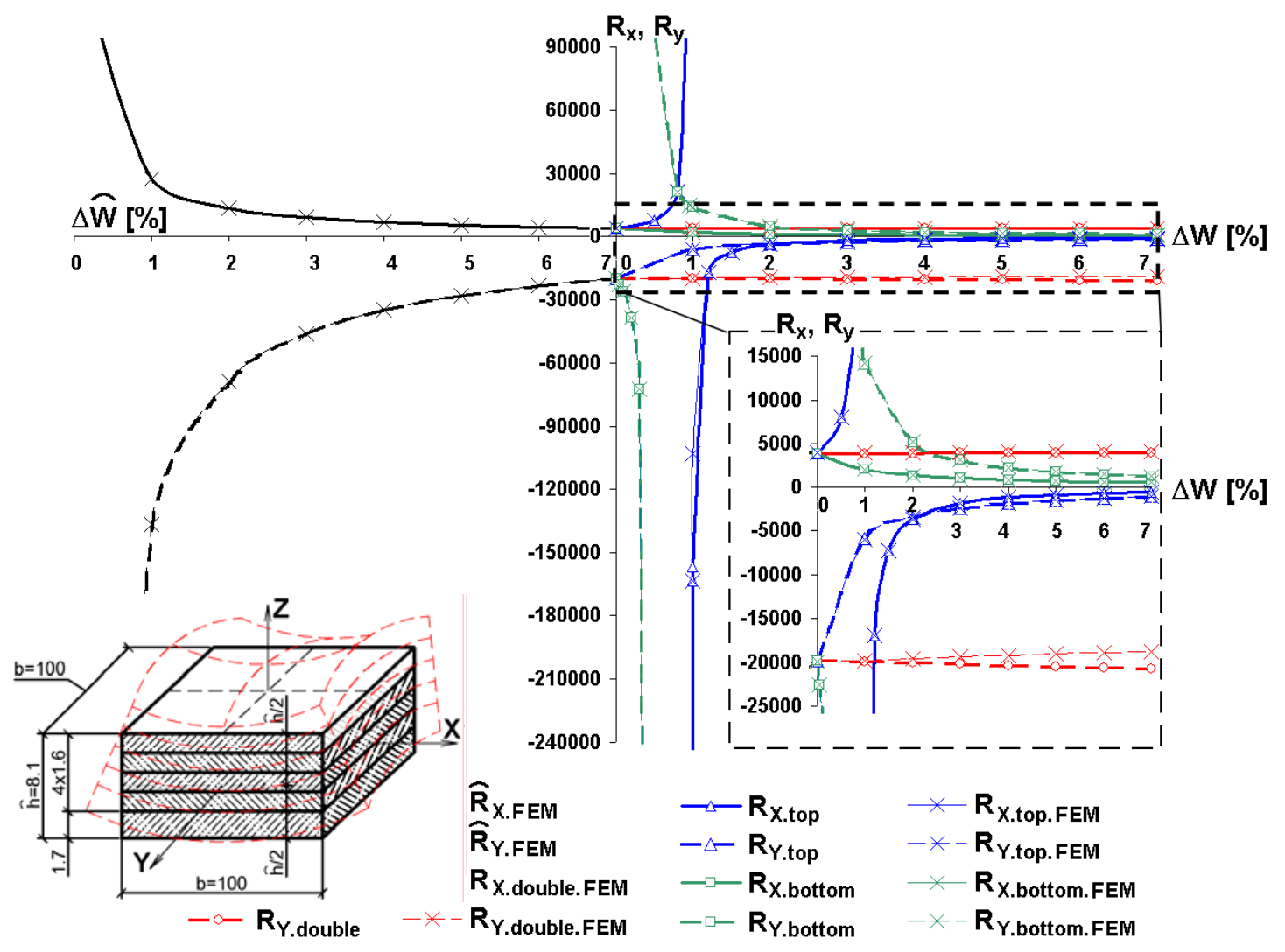

Fig. 5. Change in bending radiuses in dependence off the material moisture changes for the sheet (on the left side of graph) and for the elements (on the right side of graph) if the thickness of reinforcement is $3.15 \mathrm{~mm}$. In the right bottom corner is shown the enlarged part of curve 
a)

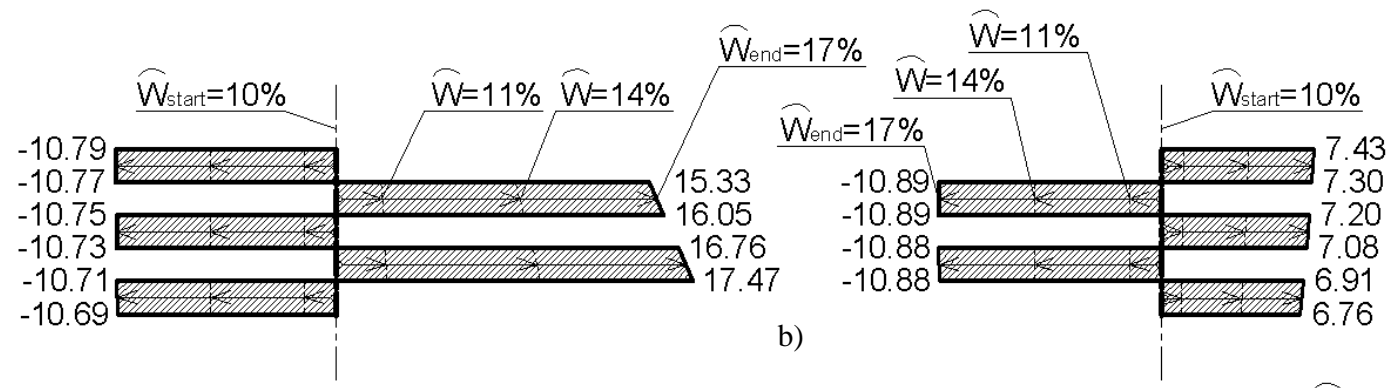

c)
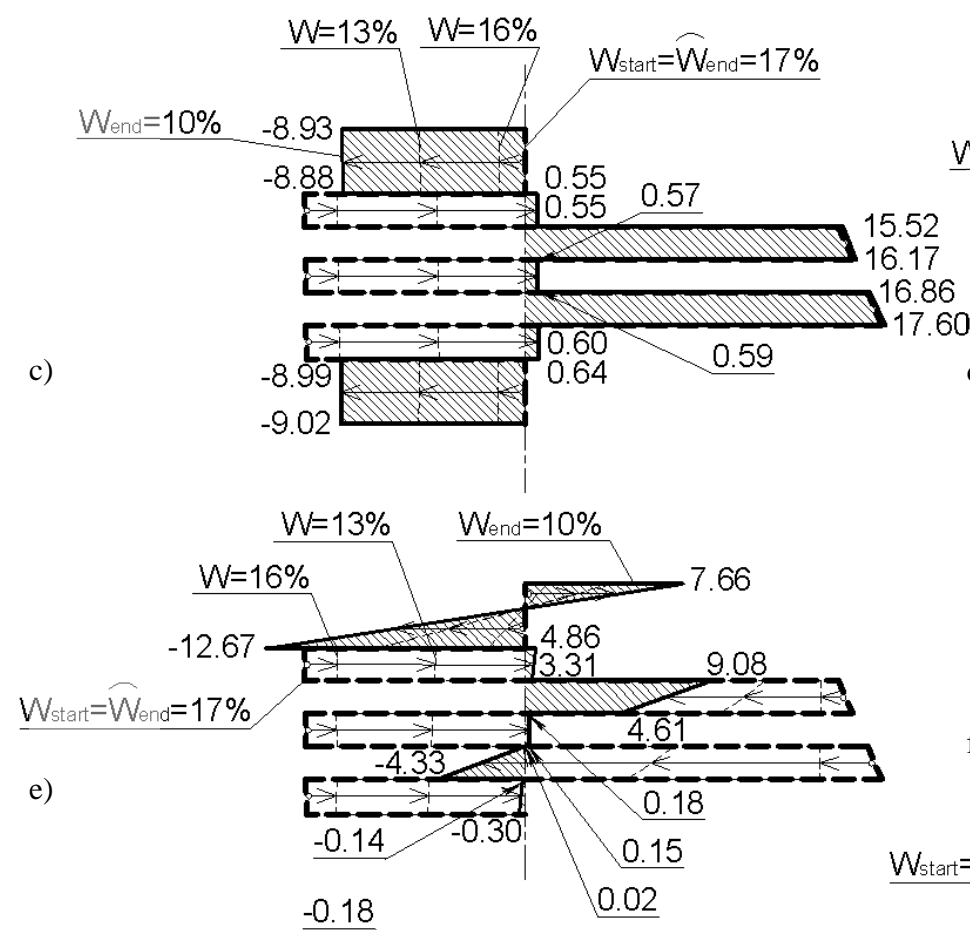

$\mathrm{W}_{\text {start }}=\widehat{W}_{\text {end }}=17 \%$

g)

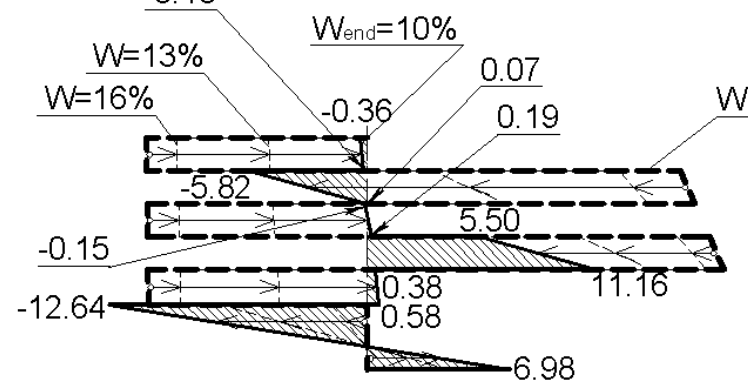

f)

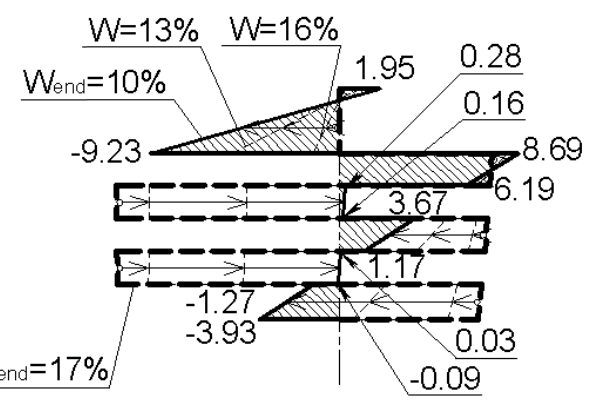

d)
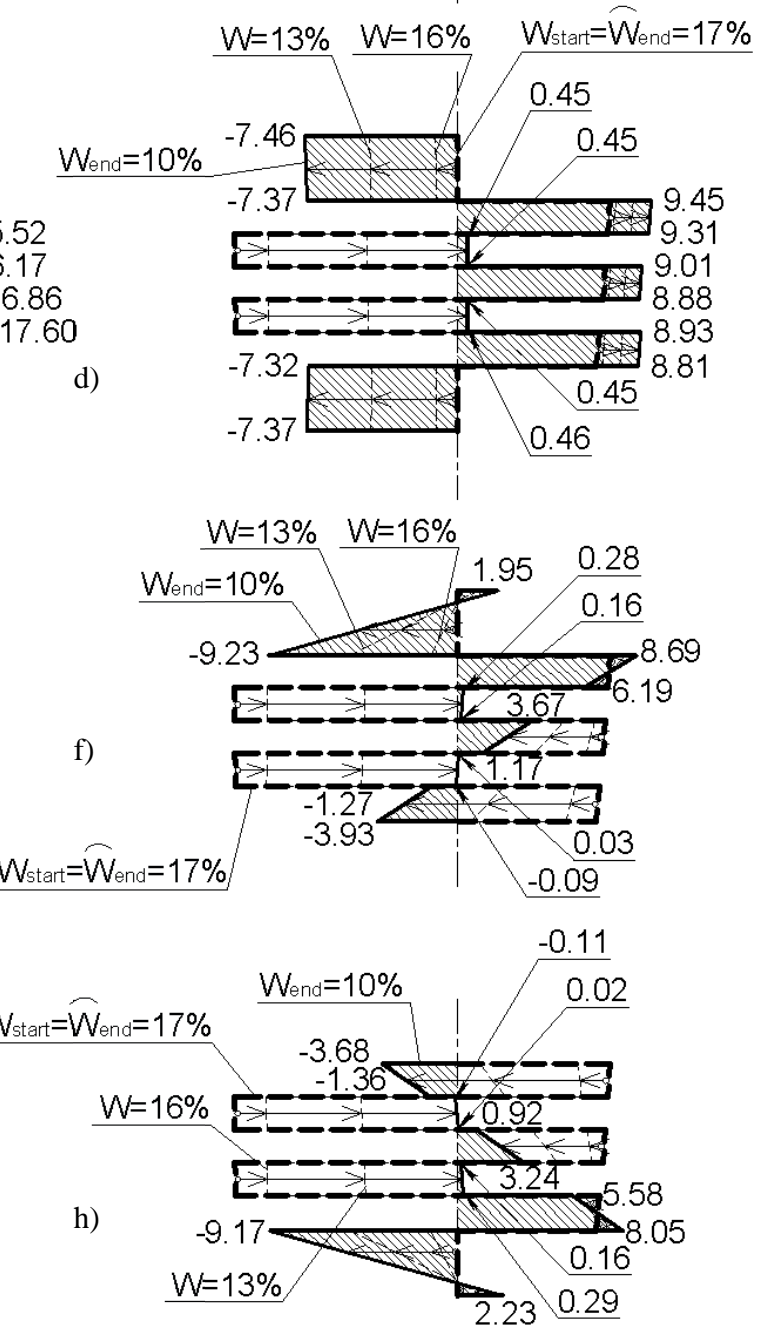

Fig. 6. Stresses a) $x$, b) $y$ in the layers of the sheet if material moisture $W$ changes from $10 \%$ to $17 \%$. Stresses c) x.double , d) y.double in the layers of the sheet curved by moisture and after that reinforced from the both sides, if timber moisture $\mathrm{W}$ changes from $17 \%$ to $10 \%$. Stresses e) x.top , f) y.top in the layers of the sheet reinforced from the top side. Stresses g) x.bottom, h) y.bottom in the layers of the sheet reinforced from the bottom side

Patterns applied in the figure:

\begin{tabular}{|c|c|}
\hline -11. 7.20 & $\begin{array}{l}\text { Line of stress diagram if moisture is } 10 \%(\mathrm{~W} \quad 0 \%) \\
\text { Stress diagram of sheet with the stress values [MPa] if moisture is } 17 \%\left(\begin{array}{ll}\mathrm{W} & 7 \%\end{array}\right)\end{array}$ \\
\hline$\stackrel{---->}{\longrightarrow--1}$ & $\begin{array}{l}\text { Stress diagrams of sheet if moisture are } 11 \%(\mathrm{~W} 1 \%) \text { and } 14 \%(\mathrm{~W} 4 \%) \text {. Stress diagrams of rein- } \\
\text { forced sheet if moisture are } 16 \%(\mathrm{~W} 1 \%) \text { and } 13 \%(\mathrm{~W} 4 \%)\end{array}$ \\
\hline & Line of stress diagram if moisture is $17 \%$ ( $\mathrm{W} \quad 7 \%$ or $\mathrm{W} \quad 0 \%$ ) \\
\hline 9.031 & Stress diagram of reindforced sheet with the stress values [MPa] if moisture is $10 \%$ ( $\mathrm{W} 7 \%$ ) \\
\hline
\end{tabular}




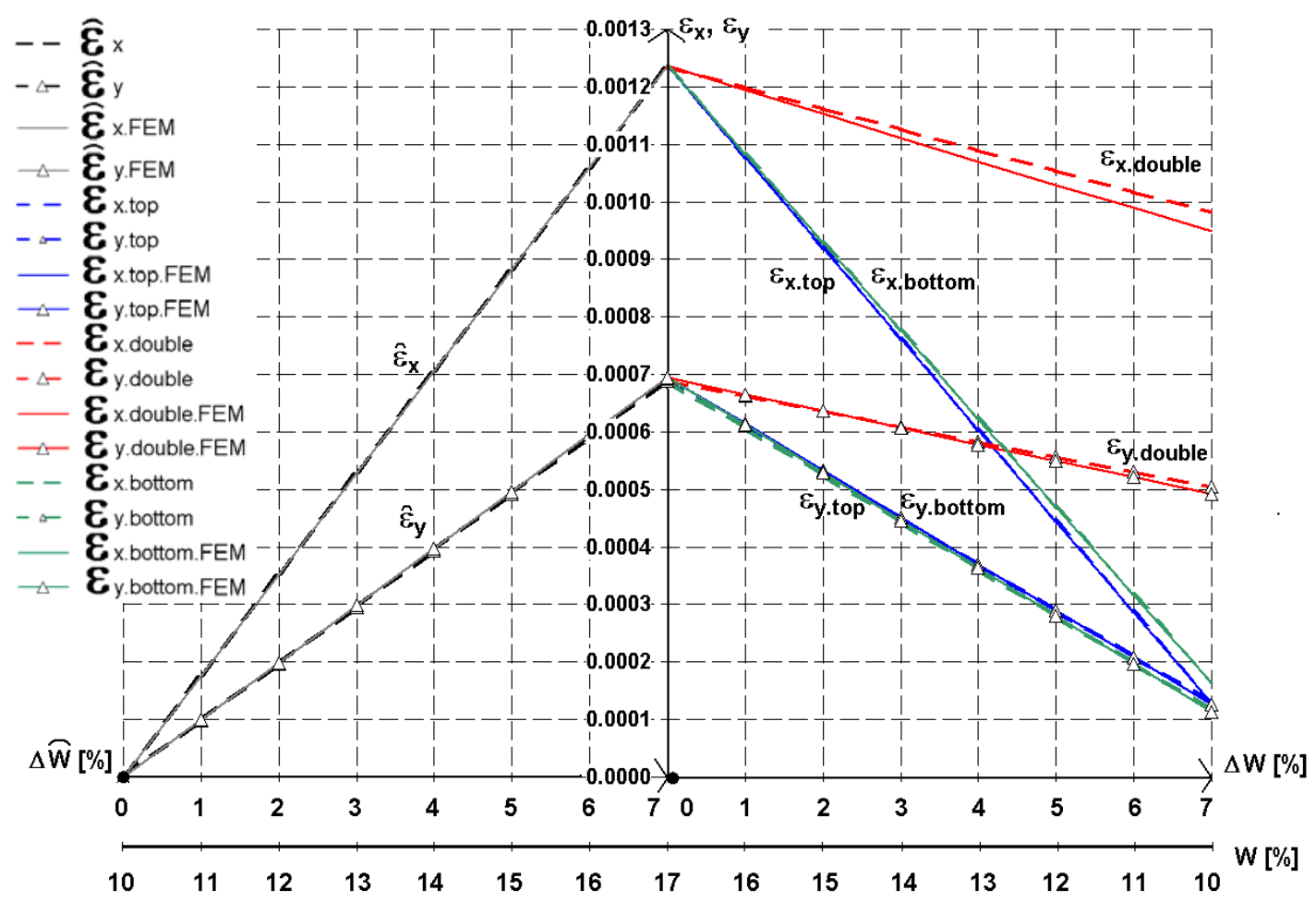

Fig. 7. Longitudinal deformations calculated with FEM and developed calculation method in the plane which coincide with the middle plane of the sheet

becomes arched with the greater value of curvature; arched curvature parallel to Y axis increases more (see Fig. 4c and 5). When the bottom surface of the sheet is reinforced with GFRP, the curvatures also tends to increase - if the moisture decrease is $\sim 0.5 \%$ (Fig. $4 \mathrm{~d}$ and 5 ) concaved curvature parallel to the direction of $\mathrm{X}$ axis increases more, but arched curvature parallel to $\mathrm{Y}$ axis changes the direction and becomes concaved with the greater value of curvature. Changes of the direction of curvatures can be explained with the changes of the placement of neutral axis following the gluing of the reinforcement, as the result the placement of the internal forces, caused by moisture changes in layers, can change, and this internal force can induce the inside moment in other direction. One-sided reinforcement is more advantageous because resulting stresses in the timber layers will be smaller than in the case of double-sided reinforcement - the part of the strength left in the timber layer and also in the all hybrid composite material is greater than in the case of double-sided reinforcement.

Stresses are calculated by FEM and picked from the contact planes of element's layers where the vertical axis intersects the centre of gravity. The stresses in the layers of the sheet, whose curvature is obtained by increasing the moisture content from $10 \%$ to $17 \%$, are shown in the stress diagrams of Figs $6 \mathrm{a}$ and $6 \mathrm{~b}$.

From analysis of changes in stresses, for the cases of above mentioned materials, layer thicknesses and orientations was concluded that the highest stresses in timber layers develop when double-sided GFRP reinforcement is used (Figs 6a and 6b), but the shape invariability is provided the best of all (Figs $4 \mathrm{~b}$ and 5). After regaining initial moisture condition there are only tension stresses in the timber layers, but only compression stresses in the both reinforcement layers. When strengthening the top side of the sheet with the GFRP reinforcement, the both tension and compression stresses develops in reinforcement (see Figs 6e and 6f), but compression stresses are larger at any moisture content. Resultant stresses in the timber layers are smaller or the same as in the case with double-sided reinforcement. In this case compression stresses develop in the two lower timber layers, but tension stresses in the others. When strengthening the bottom side of the sheet with the GFRP reinforcement, both tension and compression stresses develop in the reinforcement (Figs $6 \mathrm{~g}$ and 6h). Compression stresses in the GFRP reinforcement are larger at any moisture content, also for this case. Resultant stresses in the timber layers are smaller or the same as in the case of double-sided strengthening. In this case compression stresses develop in the two topmost timber layers, but tension stresses in the others.

Longitudinal deformations of the element are calculated in the plane which corresponds to the middle plane of the sheet using both FEM and developed calculation model (Fig. 7). As edge effects in calculation with developed model were not taken into account, developed calculation model is applicable only in the case of uniform distribution of stresses and deformations, then for the purpose of result comparison, the values of longitudinal deformations calculated by FEM were derived from the zone where the distribution of stresses and deformations between adjacent finite elements are uniform, i.e. where the distance from the edge of the sheet are equal to the length of one finite element ( $2.5 \mathrm{~mm}$ ). Difference between longitudinal deformations calculated using developed calculation model and FEM in all listed cases does not exceed 3.3\%, therefore it can be declared that developed calculation model is sufficiently 
accurate and does not gives error larger than 5\% when stiffness of the anticlastic surface and stress distribution between the layers of composite material layers are not taken into account.

\section{Conclusions}

Two variants for the determination of reinforcement thickness, which provides invariability of the sheets shape, are proposed for the anticlastic composite material sheet under variable moisture conditions - developed calculation model (Baikovs and Rocens 2006) or the finite element method (ANSYS v.11) can be used.

An opportunity to provide the original shape, not exceeding the difference of $5 \%$ for anticlastic timber composite material sheets, which consists of five glued together birch-tree layers, which are oriented at right angles towards the longitudinal fibres of adjacent layers (thickness of four top layers are $1.6 \mathrm{~mm}$, but of bottom layer $1.7 \mathrm{~mm}$ ) using glass fibre reinforced plastic reinforcement with thickness of $3.15 \mathrm{~mm}$ for the case when moisture content of layers decreases from $17 \%$ to $10 \%$ has been demonstrated

The comparison between the analytical results of proposed variants has been carried out, and established that the difference in inspected three cases - if timber composite material is reinforced on the top, bottom or both sides for all of variations does not exceed 3.3\%, when comparing values of longitudinal deformations. Maximal difference between results exceeds $2.9 \%$ only in the one of the six cases if the values of bending radiuses are compared.

\section{References}

Amburgey, T., et al. 1999. Wood handbook. Wood as engineering material. Forest Products Laboratory USDA Forest Service, Madison, Wisconsin. 486 p.

Ashton, I. E.; Halphin, I. C.; Petit, P. H. 1969. Primer on composite materials analysis. Stamford: Technomik Publ. Co. 134 p.

Baikovs, A.; Rocens, K. 2006 [online]. Stability of the shape of anticlastic composite material sheet under variable moisture conditions, in Proc. of the 5th International Conference of DAAAM Baltic, INDUSTRIAL ENGINEERING [accessed 5 May 2009] Available from Internet: $<$ http://innomet.ttu.ee/daaam06/proceedings/Materials\% 20Engineering/46Baikovs.pdf > .

Composite materials handbook. Volume 3. Polymer matrix composites. Materials usage, design, and analysis [online]. Department of defense, US army research laboratory 2002 [accessed 5 May 2009] Available from Internet: http://www.lib.ucdavis.edu/dept/pse/resources/fulltext/ HDBK17-3F.pdf.>. 693 p.

Reissner, E.; Stavsky, I. 1961. Bending and stretching of certain types of heterogeneous allotropic elastic plates, Trans. ASME. Ser. E, 28(3): 402-408.

Роценс, К.; Штейнертс, К. 1976. Оценка податливости и жесткости несбалансированных моноклинных композиций [Rocens, K.; Steinerts, K. Estimation of ductility and stiffness for unbalanced monoclinic composites], Polymer Mechanics 6: 1030-1035.

Skudra, M.; Skudra, A. 2002. Ievads slāņaino materiālu un konstrukciju mehānik $\bar{a}$ [Introduction in the laminated material and construction mechanics]. Riga: Riga Technical University. 116 p.

Tsai, S. W.; Pegano, N. I. 1968. Invariant properties of composite materials, Composite Materials Workshop. Stamford: Technomic Publ. Co., Inc., Lancaster, PA, 233-253.

Уголев, Б. Н. 2007. Древесиноведение и лесное товароведение [Ugolev, B. N. Wood science and science of forest commodities]. Москва. 351 с.

\section{MIŠRIỤ KOMPOZITINIỤ MEDŽIAGŲ ANTIKLASTINIO PAVIDALO POKYČIŲ PROGNOZĖ}

\section{A. Baikovs, K. Rocēns}

\section{S a n tra u a}

Ieškant įvairių konstrukcijų statinių konstrukciškai geresnių ir estetiškai patrauklesnių sprendinių, dažniausiai naudojami nestandartiniai antiklastiniai elementai. Todèl buvo tyrinėtas medienos kompozitinės medžiagos lakštų pradinio pavidalo išsaugojimas naudojant sustiprintą plastiko armatūrą. Skaičiuojamasis modelis, padedantis nustatyti racionaliai armuoto antiklastinio lakšto storị, kuris pakeičia pradinị lenkimo spinduli kintamomis drègmės sąlygomis (Baikovs, Rocens 2006) tarp priimtinų intervalų ribű yra sukurtas autorių ir, taikant baigtinių elementų metodą, lakšto deformacijų skaičiavimai bei modeliavimas atlikti kompiuterinių programų paketu ANSYS v.11 (toliau - FEM) ir pagal sukurtą analitinį metodą. Rezultatu̧, apskaičiuotų su FEM ir pagal sukurtą analitinį modeli, lyginamasis tyrimas parodė, kad skirtumas tarp trijų tirtų atvejŭ, kai medienos kompozitinè medžiaga yra armuota viršuje, apačioje ir iš abiejų pusių, rezultatai daugeliu atvejų neviršija 3,3 \%. Parodyta galimybė suteikti originalų pavidalą antiklastiniams medienos kompozitiniams lakštams naudojant stiklo pluoštu sustiprinto plastiko armatūrą ịvairiomis drëgmės sąlygomis ir neviršijant 5 \% skirtumo.

Reikšminiai žodžiai: poslinkiai, drėgmės sąlygos, medienos kompozitinė medžiaga, stiklo pluošto plastikas, armatūra.

Andris BAIKOVS is a doctoral student at Riga Technical University and certified senior building engineer in the Building Unit of Design department at the stock company "High voltage network", Latvia. His research interests include the modern structures and technological mechanics of composite materials.

Kārlis ROCĒNS is a professor of structural engineering and director of the Institute of Structural Engineering and Reconstruction at the Riga Technical University, Latvia. He is a Full member of Latvian academy of sciences and participant from Latvia in COST activity C25 "Sustainability of construction: Integrated approach to life time structural engineering”. His research interests include the modern structures, technological mechanics of wood and composite materials and structural material science. 